\title{
Clinical utility gene card for: $\alpha$-1-antitrypsin deficiency
}

\author{
Sabina Janciauskiene ${ }^{\star, 1}$, Ilaria Ferrarotti ${ }^{2}$, Florian Laenger ${ }^{3}$, Danny Jonigk ${ }^{3}$ and Maurizio Luisetti ${ }^{2}$ \\ European Journal of Human Genetics (2011) 19; doi:10.1038/ejhg.2010.246; published online 19 January 2011
}

\section{DISEASE CHARACTERISTICS}

1.1 Name of the disease (synonyms)

$\alpha$-1-antitrypsin deficiency (AATD).

\subsection{OMIM\# of the disease}

613490 .

1.3 Name of the analysed genes or DNA/chromosome segments $\alpha-1$ protease inhibitor $(P I) / \alpha$-1-antiproteinase $(A A T) /$ serpin A1. ORF names: PRO0684, PRO2209.

\subsection{OMIM\# of the gene(s)}

107400.

\subsection{Mutational spectrum}

At least 60 deficient mutations have been described. They comprise single point mutations, truncated (nonsense, frameshift and splicing) mutations, deletions of single codons and larger deletions. Most of them are located in the four coding exons of the gene. The most common deficient variants are named Z (G/A, Glu342Lys, in exon V) and S (A/T, Glu264Val, in exon III).

\subsection{Analytical methods}

Genotyping for $\mathrm{S}$ and $\mathrm{Z}$ variants by PCR-restriction fragment length polymorphism or melting probes. Direct coding exons sequencing of the gene. Sequencing is the final procedure carried out to determine the actual variant(s) when genotyping is unable to provide a complete identification of both AATD alleles. ${ }^{1}$

\subsection{Analytical validation}

Internal validation through analysis of known mutations. External validation through exchange of DNA control samples with other diagnostic institutions.

\subsection{Estimated frequency of the disease}

(incidence at birth ('birth prevalence') or population prevalence) In populations of Caucasian origin the prevalence of the disease is 25 out of 10000 (http://www.orpha.net/orphacom/cahiers/docs/GB/ Prevalence_of_rare_diseases_by_alphabetical_list.pdf). The highest prevalence of $\mathrm{PI}^{\star} \mathrm{Z}$ variants was recorded in northern and western European countries (mean gene frequency 0.0140); it gradually decreases throughout European countries in a northwest/southeast direction. On the contrary, the highest frequency of $\mathrm{PI}^{\star} \mathrm{S}$ variant is in southern Europe (mean gene frequency 0.0564) and it gradually decreases along a southwest/northeast gradient. ${ }^{2}$ In the USA, the highest risk for AATD is found in Whites, followed by Hispanics and Blacks with the lowest prevalence among Mexican Americans and no risk among Asians. ${ }^{3}$

\subsection{If applicable, prevalence in the ethnic group of investigated} person

The comprehensive analysis of genetic epidemiology studies on AATD in different cohorts allowed the estimation of prevalence of $\mathrm{PI}^{\star} \mathrm{S}$ and $\mathrm{PI}^{\star} \mathrm{Z}$ alleles. ${ }^{4,5}$ According to these data, Germany and Italy have a mean prevalence of 0.021 and 0.027 , respectively, for $S$ mutation and 0.0099 and 0.070 , respectively, for $\mathrm{Z}$ mutation.

\subsection{Diagnostic setting}

\begin{tabular}{llc}
\hline & Yes & No \\
A. (Differential) diagnostics & $\bigotimes$ & $\square$ \\
B. Predictive testing & $\bigotimes$ & $\square$ \\
C. Risk assessment in relatives & $\bigotimes$ & $\square$ \\
D. Prenatal & $\bigotimes$ & $\square$ \\
\hline
\end{tabular}

\section{Comment:}

A prenatal test for AATD is rarely requested. Prenatal diagnosis can be discussed in selected cases, that is, couples requesting it because of familial occurrence of severe AATD.

\section{TEST CHARACTERISTICS}

\begin{tabular}{|c|c|c|c|c|}
\hline & \multicolumn{2}{|c|}{ Genotype or disease } & \multirow{2}{*}{$\begin{array}{l}\text { A: True positives } \\
\text { B: False positives }\end{array}$} & \multirow{2}{*}{$\begin{array}{l}\text { C: False negative } \\
\text { D: True negative }\end{array}$} \\
\hline & Present & Absent & & \\
\hline \multicolumn{5}{|l|}{ Test } \\
\hline \multirow[t]{2}{*}{ Positive } & A & $\mathrm{B}$ & Sensitivity: & $A /(A+C)$ \\
\hline & & & Specificity: & $D /(D+B)$ \\
\hline \multirow[t]{2}{*}{ Negative } & C & $\mathrm{D}$ & Positive predictive value: & $A /(A+B)$ \\
\hline & & & Negative predictive value: & $D /(C+D)$ \\
\hline
\end{tabular}

\subsection{Analytical sensitivity}

(proportion of positive tests if the genotype is present)

Almost 100, if the diagnostic procedure is correct. ${ }^{1}$ It could be less if only exons are analysed.

\subsection{Analytical specificity}

(proportion of negative tests if the genotype is not present) Almost 100, if the diagnostic procedure is correct. ${ }^{1}$

\footnotetext{
${ }^{1}$ Department of Pulmonology, Hannover Medical School, Hannover, Germany; ${ }^{2}$ Center for Diagnosis of Inherited Alpha1-antitrypsin Deficiency, Laboratory of Biochemistry and Genetics, Institute for Respiratory Disease, University of Pavia, Fondazione IRCCS Policlinico San Matteo, Pavia, Italy; ${ }^{3}$ Institute of Pathology, Hannover Medical School, Hannover, Germany

*Correspondence: Dr S Janciauskiene, Department of Pulmonology, Hannover Medical School, Feodor-Lynen Street 23, Hannover 30625 , Germany. Tel: +49 511 532 7297 ;

Fax: +49 511532 7294; E-mail: janciauskiene.sabina@mh-hannover.de
} 
2.3 Clinical sensitivity

(proportion of positive tests if the disease is present)

The clinical sensitivity can be dependent on variable factors such as age or family history. In such cases, a general statement should be given, even if a quantification can only be made case by case.

The diagnosis of AATD is generally made after the identification of COPD or chronic liver disease, the two clinical phenotypes mostly associated with AATD, or after AATD diagnosis in a family member. The frequency of AATD-associated COPD cases is about $1-2 \%$ of overall COPD patients. ${ }^{6}$ Other disease associations with AATD include panniculitis, antineutrophil cytoplasmic antibody vasculitis (eg, Wegener's granulomatosis) and bronchiectasis.

\subsection{Clinical specificity}

(proportion of negative tests if the disease is not present)

The clinical specificity can be dependent on variable factors such as age or family history. In such cases a general statement should be given, even if a quantification can only be made case by case.

SERPINA1 gene penetrance is limited and, in particular, the $\mathrm{PI}^{\star} \mathrm{Z}$ mutation is characterised by an incomplete penetrance; therefore, the relationship between genotype and clinical phenotype is not strong. In a study of 54 individuals who were clinically healthy when AATD was identified, only one-third, almost all smokers, had developed COPD between 30 and 60 years of age. ${ }^{7}$ Regarding prevalence of chronic liver disease in the general population, several reports have observed that the prevalence of $\mathrm{PI}^{\star} \mathrm{ZZ}$ in patients with chronic liver disease is about $0.8 \% .^{6}$ Panniculitis has been recognized as a rare complication of AATD with an estimated prevalence of approximately 1 per $1000 .^{8}$

\subsection{Positive clinical predictive value}

(life-time risk to develop the disease if the test is positive)

The majority of children with AATD with the $\mathrm{Z}$ protein phenotype who are identified through newborn screening have abnormal liver function tests at some point during their first year of life. Approximately $10 \%$ of infants with the $\mathrm{Z}$ protein phenotype have prolonged obstructive jaundice, and about $2 \%$ of children with liver failure require liver transplantation. ${ }^{9}$ As these children age, there is an increasing risk of liver disease, including cirrhosis and hepatocellular carcinoma. $^{10}$

COPD that is associated with AATD rarely develops before the age of 30 years. ${ }^{11}$ The classic pulmonary presentation of AATD is severe, early-onset panacinar emphysema with a basal predominance in adults (after fourth-fifth decade of age). Cigarette smoking greatly increases the risk of COPD in patients with the $\mathrm{Z}$ protein phenotype. $^{12}$

\subsection{Negative clinical predictive value}

(probability not to develop the disease if the test is negative)

Assume an increased risk based on family history for a non-affected person. Allelic and locus heterogeneity may need to be considered.

Index case in that family had been tested: $100 \%$.

Index case in that family had not been tested:

Can only be clarified through analysis of the non-affected person.

\section{CLINICAL UTILITY}

3.1 (Differential) diagnosis: The tested person is clinically affected (To be answered if in 1.10 'A' was marked)

3.1.1 Can a diagnosis be made other than through a genetic test?

\begin{tabular}{lll}
\hline No & $\square$ (continue with 3.1.4) & \\
Yes & $\square$ \\
& Clinically & $\square$ \\
Imaging & $\square$ \\
& Endoscopy & $\square$ \\
& Biochemistry & $\square$ \\
& Electrophysiology & \\
& Other (please describe) & \\
&
\end{tabular}

\subsubsection{Describe the burden of alternative diagnostic methods to the} patient

Biochemical diagnosis of AATD can be made through evaluation of plasma level and isoelectric focusing of AAT, but the latter is laborconsuming, requires specific expertize, and it is characterized by low sensitivity, as it does not recognize Null and M-like alleles. Clinical diagnosis of AATD is impossible, as its clinical phenotypes are not pathognomonic. On the other hand, intra-hepatic inclusions positive for periodic acid-schiff, resistant to diastase and immunoreactive to AAT protein, and the lower distribution of emphysema on chest radiographs and CT scan, are often highly suggestive of AATD and should prompt genotyping.

3.1.3 How is the cost effectiveness of alternative diagnostic methods to be judged?

Unknown.

3.1.4 Will disease management be influenced by the result of a genetic test?

No $\square$

Yes $\otimes$

Therapy Treatments include, such as bronchodilators, anti-inflamma-

(please tory drugs, antibiotics and supplemental oxygen. Augmentation

describe) therapy with plasma purified $\alpha-1$-antiproteinase is recommended if lung disease is present. If lung disease progresses, patient may be evaluated for lung volume reduction surgery or lung transplantation. Liver transplantation performed in severe liver diseases.

Prognosis Deficient mutations reduce the concentration of $\alpha$-1-anti(please proteinase in lungs, which leads to protease/anti-protease describe) imbalance and, therefore, facilitate the development of emphysema. Moreover, $\mathbf{Z}$ mutations cause the polymerization of $\alpha$-1-antiproteinase protein inside hepatocytes, which may led to liver diseases. A liver biopsy in such cases will reveal periodic acid-schiff-positive, diastase-negative granules. Adults with $\alpha$-1-antiproteinase deficiency-associated genotypes develop liver disease less frequently than pulmonary manifestations. However, $\alpha-1$-antiproteinase is a relevant cause for liver cirrhosis, after viral hepatitis, alcohol abuse and chronic cholangitis. Individuals carrying rare AATD variants are characterized by a rather peculiar phenotypic profile, placing them in a precise position within the spectrum of genotypephenotype correlations in $\alpha$-1-antiproteinase. For example, Mheerlen and Mprocida have low serum $\alpha$-1-antiproteinase levels due to intracellular degradation of protein, ${ }^{13,14}$ Mmalton and Siiyama ${ }^{15,16}$ are associated with intracellular accumulation of protein, whereas Null alleles are at greater risk to lung disease. ${ }^{17}$ The careful characterization of deficient allele(s) that cause AATD is important to evaluate the risk for lung disease, and may help to estimate the development of liver disease. 


\section{(Continued)}

Management The results of genetic tests will influence genetic counselling by (please permitting predictive testing of asymptomatic family members.

describe) Patients with AATD due to mutation that polymerize inside hepatocytes also need extensive follow-up of liver function. Cigarette smoking is firmly established as the major factor associated with accelerated decline of lung function in AATD. ${ }^{7}$ For current smokers, smoking cessation counselling is mandatory.

3.2 Predictive setting: The tested person is clinically unaffected but carries an increased risk based on family history

(To be answered if in 1.10 ' $\mathrm{B}$ ' was marked)

\subsubsection{Will the result of a genetic test influence lifestyle and prevention?}

If the test result is positive (please describe):

The identification of individuals with mutations predisposing to AATD can motivate these individuals to avoid risk factors for symptomatic disease, such as cigarette smoking and exposure to environmental pollutants. Early detection of severe AATD would enable individuals to make changes in their lifestyle (active and passive smoking cessation; exercising and pulmonary rehabilitation; nutritional support, long-term oxygen therapy for the severe and very severe AATD patients with respiratory insufficiency) to prevent the development of severe morbidity. ${ }^{18}$ Regular lung function tests are recommended for early recognition of airway obstruction. Vaccination against pneumococci and annual influenza vaccination may reduce the incidence of airway infections, and, in established liver disease, hepatitis A and B vaccination are suggested.

If the test result is negative (please describe):

If the test is negative, no preventive measures are required.

3.2.2 Which options in view of lifestyle and prevention does a person at-risk have if no genetic test has been done (please describe)?

Smoking cessation advice and passive smoking prevention are mandatory irrespective of a genetic testing.

3.3 Genetic risk assessment in family members of a diseased person (To be answered if in 1.10 ' $\mathrm{C}$ ' was marked)

3.3.1 Does the result of a genetic test resolve the genetic situation in that family?

Yes.

3.3.2 Can a genetic test in the index patient save genetic or other tests in family members?

No.

3.3.3 Does a positive genetic test result in the index patient enable a predictive test in a family member?

Yes.

\subsection{Prenatal diagnosis}

(To be answered if in 1.10 'D' was marked).

3.4.1 Does a positive genetic test result in the index patient enable a prenatal diagnosis?

A prenatal diagnosis is almost never requested and should be performed only exceptionally, in reasonable cases with clear indication and after extensive genetic counseling.

\section{IF APPLICABLE, FURTHER CONSEQUENCES OF TESTING}

Please assume that the result of a genetic test has no immediate medical consequences. Is there any evidence that a genetic test is nevertheless useful for the patient or his/her relatives? (Please describe).

The genetic diagnosis of AATD has clinical validity for both index cases and their relatives. Appropriate predictive genetic testing of family members should establish their risk for the disorder. Additional benefits may be realised with regards to lifestyle planning. In occasion of a large neonatal screening for AATD in Sweden, 50\% of the AATD individuals thought that the knowledge of their high-risk condition had affected their lives, particularly their awareness of the dangers of smoking and environmental pollution. The majority, $88 \%$, knew that they should avoid smoking to protect their lung. Indeed the majority of those who were identified through screening and their parents would recommend screening for AATD. ${ }^{19}$

\section{CONFLICT OF INTEREST}

The authors declare no conflict of interest.

\section{ACKNOWLEDGEMENTS}

This work was supported by the EuroGentest, an EU-FP6 supported NoE, contract number 512148 (EuroGentest Unit 3: 'Clinical genetics, community genetics and public health', Workpackage 3.2)

1 Miravitles M, Herr C, Ferrarotti I et al: Laboratory testing of individuals with severe a1-antitrypsin deficiency in three European centres. Eur Respir J 2010; 35: 960-968.

2 Luisetti M, Seersholm N: Epidemiology of alpha1-antitrypsin deficiency. Thorax 2004; 59: 164-169.

3 DeSerres FJ, Blanco I, Fernandez-Bustillo E: Ethnic differences in alpha-1 antitrypsin deficiency in the United States of America. Ther Adv Respir Dis 2010; 4: 63.

4 De Serres FJ, Luisetti M, Ferrarotti I, Blanco I, Fernandez-Bustillo E: Alpha-1 antitrypsin deficiency in Italy: regional differences of the PIS and PIZ deficiency alleles. Monaldi Arch Chest Dis 2005; 63: 133-141.

5 Bals R, Koczulla R, Kotke V, Andress J, Blackert K, Vogelmeier C: Identification of individuals with alphal-antitrypsin deficiency by a targeted screening program. Respir Med 2007; 101: 1708-1714.

6 American Thoracic Society; European Respiratory Society: American Thoracic Society/ European Respiratory Society statement: standards for the diagnosis and management of individuals with alpha-1 antitrypsin deficiency. Am J Respir Crit Care Med 2003; 168: 818-900.

7 Silverman EK, Pierce JA, Province MA, Rao DC, Campbell EJ: Variability of pulmonary function in alpha-1-antitrypsin deficiency: clinical correlates. Ann Intern Med 1989; 111: 982-991.

8 McElvaney NG, Stoller JK, Buist AS et al: Baseline characteristics of enrollees in the National Heart, Lung and Blood Institute Registry of alpha 1-antitrypsin deficiency. Chest 1997; 111: 394-403.

9 Sveger T: The natural history of liver disease in alpha 1-antitrypsin deficient children. Acta Paediatr Scand 1988; 77: 847-851.

10 Piitulainen E, Sveger T: Effect of environmental and clinical factors on lung function and respiratory symptoms in adolescents with alphal-antitrypsin deficiency. Acta Paediatr 1998; 87: 1120-1124.

11 Bernspång E, Sveger T, Piitulainen E: Respiratory symptoms and lung function in 30-yearold individuals with alpha-1-antitrypsin deficiency. Respir Med 2007; 101: 1971-1976.

12 Mayer AS, Stoller JK, Vedal S et al: Risk factors for symptom onset in PI*Z alpha-1 antitrypsin deficiency. Int J Chron Obstruct Pulmon Dis 2006; 1: 485-492.

13 Poller W, Merklein F, Schneider-Rasp $S$ et al: Molecular characterisation of the defective alpha 1-antitrypsin alleles PI Mwurzburg (Pro369Ser), Mheerlen (Pro369Leu), and Q0lisbon (Thr68lle). Eur J Hum Genet 1999; 7: 321-331.

14 Lee J, Novoradovskaya N, Rundquist B, Redwine J, Saltini C, Brantly M: Alpha 1 -antitrypsin nonsense mutation associated with a retained truncated protein and reduced mRNA. Mol Genet Metab 1998; 63: 270-280.

15 Carrell RW, Lomas DA: Alpha1-antitrypsin deficiency - a model for conformational diseases. N Engl J Med 2002; 346: 45-53.

16 Gooptu B, Lomas DA: Conformational pathology of the serpins: themes, variations, and therapeutic strategies. Annu Rev Biochem 2009; 78: 147-176.

17 Fregonese L, Stolk J, Frants RR, Veldhuisen B: Alpha-1 antitrypsin Null mutations and severity of emphysema. Respir Med 2008; 102: 876-884.

18 Ferrarotti I, Gorrini M, Scabini R et al: Secondary outputs of Alpha1-antitrypsin deficiency targeted detection programme. Respir Med 2008; 102: 354-358.

19 Sveger T, Thelin T, McNeil TF: Young adults with alpha 1-antitrypsin deficiency identified neonatally: their health, knowledge about and adaptation to the high-risk condition. Acta Paediatr 1997; 86: 37-40. 